NASZA DERMATOLOGIA Online OUR DERMATOLOGY Online

Source of Support:

Nil

Competing Interests:

None

\section{EPONYMS IN THE DERMATOLOGY LITERATURE LINKED TO NETHERLANDS}

\author{
Khalid Al Aboud ${ }^{1}$,Ahmad Al Aboud ${ }^{2}$ \\ ${ }^{1}$ Department of Public Health, King Faisal Hospital, Makkah, Saudi Arabia \\ ${ }^{2}$ Dermatology Department, King Abdullah Medical City, Makkah, Saudi Arabia
}

Corresponding author: Dr. Khalid Al Aboud

amoa65@hotmail.com
The Netherlands is a constituent country of the Kingdom of the Netherlands, consisting of twelve provinces in North-West Europe and three islands in the Caribbean. The Netherlands has an estimated population of 16,778,806 (as of 31 January 2013). The official language is Dutch, which is spoken by the vast majority of the inhabitants. In May 2011, the Netherlands was ranked as the "happiest” country according to results published by the The Organisation for Economic Co-operation and
Development (OECD). It is, also, one of the world's 10 leading exporting countries [1].

There are many medical eponyms originated from Netherlands. The famous website, who named it, listed more than 45 medical eponyms linked to Netherlands. In Table I [2-11], we listed highlighted on selected eponyms, in dermatology literature linked to Netherlands.

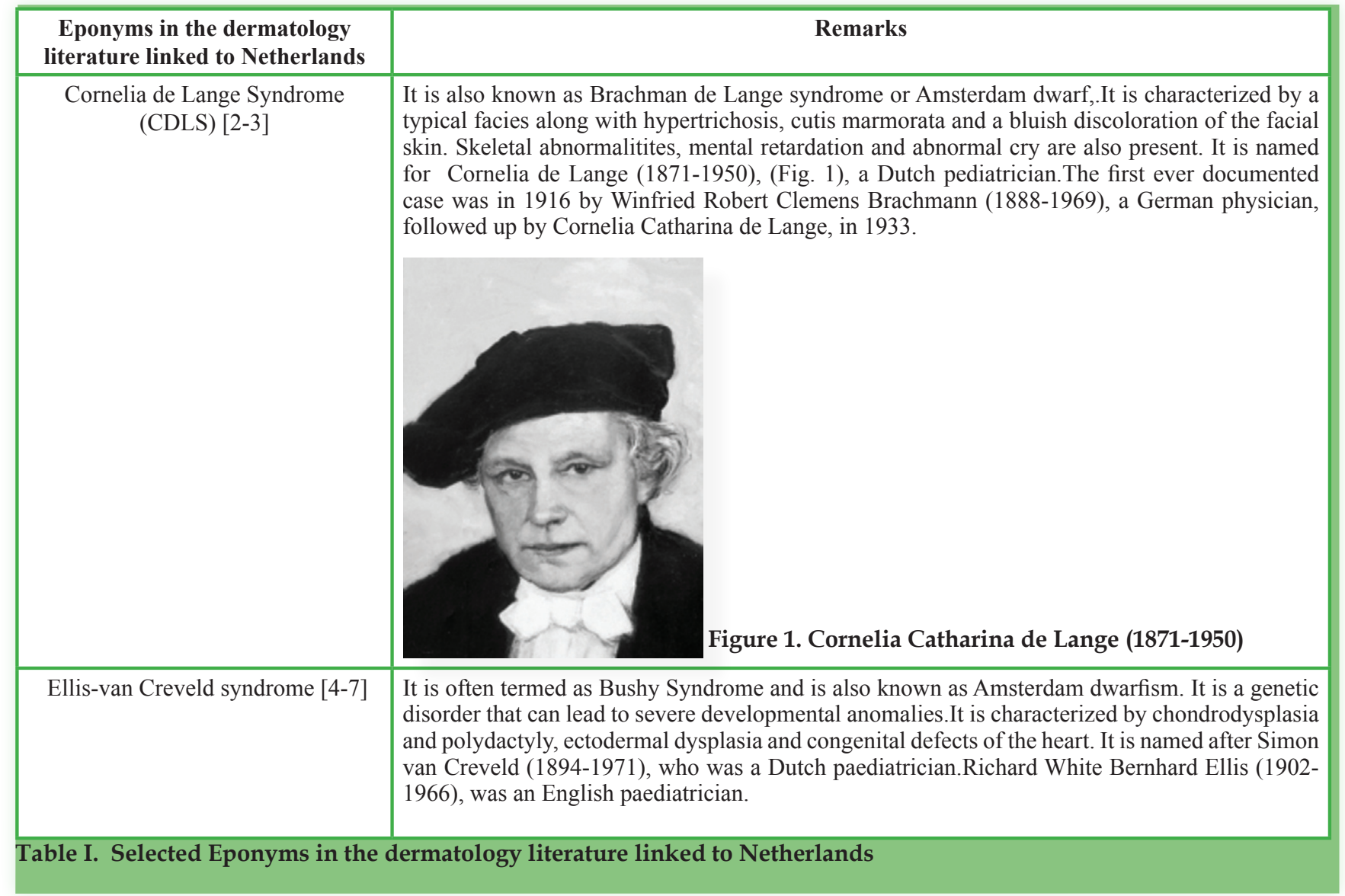




\begin{tabular}{|c|c|}
\hline $\begin{array}{l}\text { Eponyms in the dermatology } \\
\text { literature linked to Netherlands }\end{array}$ & Remarks \\
\hline Waardenburg syndrome (WS) [8-11] & $\begin{array}{l}\text { It is a rare autosomal dominant or autosomal recessive disorder that is characterized by various } \\
\text { combinations of clinical features. WS is named after a Dutch ophthalmologist, Petrus Johannes } \\
\text { Waardenburg (1886-1979), (Fig. 2), who described the syndrome in 1951. } \\
\text { The major criteria are sensorineural hearing loss, iris pigmentary abnormality (two eyes different } \\
\text { color or iris bicolor or characteristic brilliant blue iris), hair hypopigmentation (white forelock or } \\
\text { white hairs at other sites on the body), dystopia canthorum (lateral displacement of inner canthi) } \\
\text { and the presence of a first-degree relative previously diagnosed with WS. } \\
\text { WS type } 2 \text { lacks dystopia canthorum of WS1. Apart from the associated upper limb anomalies } \\
\text { (e.g. hypoplasia, syndactyly) WS type } 3 \text { (WS3; Klein- Waardenburg syndrome) is similar to } \\
\text { WS1. In addition to the features of WS1, type } 4 \text { WS (WS4; Shah- Waardenburg syndrome) is } \\
\text { associated with features of Hirschsprung disease. } \\
\text { David Klein (1908-1993), was a Swiss human geneticist and ophthalmologist.Krishnakumar N. } \\
\text { Shah, was an Indian physician. Harald Hirschsprung (1830-1916), was a Danish paediatrician. }\end{array}$ \\
\hline
\end{tabular}

\section{REFERENCES}

1. Netherlands.Wikipedia ${ }^{\circledR}$ [Internet]. Wikimedia Foundation. [Updated 30 April 2013; cited 30 April 2013]. Available from: http:// en.wikipedia.org/wiki/Netherlands

2. Hakulinen E: [The woman behind the syndrome: Cornelia de Lange. A successful scientist--a popular pediatrician]. Lakartidningen. 1988;85:2195-6.

3. Muhammed K, Safia B: Cornelia de Lange syndrome. Indian J Dermatol Venereol Leprol. 2003;69:229-31.

4. Emed A: [Simon Van Creveld (1894-1971)]. Harefuah. 2000;138:418-9.

5. Jenkins S, Morrell DS: Ellis-van Creveld syndrome: case report and review of the literature. Cutis. 2009;83:303-5.

6. Bhat YJ, Baba AN, Manzoor S, Qayoom S, Javed S, Ajaz H: Ellisvan Creveld syndrome with facial hemiatrophy. Indian J Dermatol Venereol Leprol. 2010;76:266-9.
7. Jayaraj D, Maheswaran T, Suresh R, Ganapathy N: Ellis-van Creveld. J Pharm Bioallied Sci. 2012;4(Suppl 2):S153-6.

8. Waardenburg PJ: A new syndrome combining developmental anomalies of the eyelids, eyebrows, and nose root with pigmentary defects of the iris and head hair with congenital deafness. Am J Hum Genet. 1951;3:195-253.

9. Opitz JM: In memoriam: Petrus Johannes Waardenburg, 1886-1979. Am J Med Genet. 1980;7:35-9.

10. Williamson KF: Petrus Johannes Waardenburg, MD. Br J Ophthalmol. 1980;643:224.

11. Ghosh SK, Bandyopadhyay D, Ghosh A, Biswas SK, Mandal RK: Waardenburg syndrome: a report of three cases. Indian J Dermatol Venereol Leprol. 2010;76:550-2.

Copyright by Khalid Al Aboud, et al. This is an open access article distributed under the terms of the Creative Commons Attribution License, which permits unrestricted use, distribution, and reproduction in any medium, provided the original author and source are credited. 